\title{
Multi Criteria and Landfill Site Selection Using Gis: A Case Study From Palestine
}

\author{
I. Mahamid ${ }^{1}$ and S. Thawaba ${ }^{2 * *}$ \\ ${ }^{I}$ Department of Civil Engineering, Birzeit University, Ramallah, Palestine \\ ${ }^{2}$ Department of Architectural Engineering, Birzeit University, Ramallah, Palestine
}

\begin{abstract}
Shortage of land for waste disposal and inappropriate landfill site is one of the biggest problems in most of large urban areas. Therefore more efforts are needed to overcome this problem. Most of the landfill sites in Palestine are selected randomly, and waste is burned and not treated, which impacts nature and human. The main aim of this research is to determine a suitable landfill site with less impact on environment. In this research, a potential site for an appropriate landfill area for Ramallah Governorate was determined by using geographic information system (GIS) as a tool to aid the decision making process. To achieve this purpose, thematic layers and different tabular data such as topography, land use, roads network, ground and surface water, infrastructure, and urban areas were collected from different institutions and governmental agencies in Palestine. Thematic maps were used to create the vulnerability map for the area and the result was compiled to the buffer zones around sensitive areas. By using multi-criteria analysis, a candidate site was allocated taking into consideration the sensitive areas in order to find out the best location for the anticipated regional landfill site.
\end{abstract}

Keywords: Landfill, GIS, solid waste, Palestine, vulnerability, municipal waste, sustainable urban development.

\section{BACKGROUND}

Shortage of land for waste disposal and inappropriate landfill site is one of the biggest problems in most of large urban areas in the world which has its negative impact on human, and environment [1]. Therefore more efforts are needed to overcome this problem that leads different agencies and establishments to find common limitations to protect human and environment from these concequences [2].

The U.S. Environmental Protection Agency [3] issued many regulations and limitations to control unfriendly environment projects, one of these is landfill site criteria, and also many agencies in different countries of the developed world were established to control this process. Developing countries just started to establish such agencies and institutions in this field [4].

The issue of landfill site selection was complicated and time consuming. During the last few decades and particularly when environmental planning emerged this issue became systematic and technical. The evolution of GIS made this field much easier and manageable. GIS gave the ability and functionality to find best location for certain purposes with many limitations.

GIS has very distinguishing, powerful functions and can play an important role in decision making and planning process. "The most distinguishing parts of a GIS are its functions for spatial analysis, i.e. operators that use spatial data to derive new geoinformation. Spatial queries and process models play an important role in satisfying user needs. The

*Address correspondence to this author at the Department of Architectural Engineering, Birzeit University, Ramallah, Palestine; Tel: 00970599645050; Fax: 00970-2-2982984; E-mail: sthawaba@birzeit.edu integration of database, GIS software, rules, and reasoning mechanism (implemented as a so-called inference engine) leads to what is sometimes called a spatial decision support system (SDSS)" [5].

\section{STUDY SITE}

Ramallah district is located in the middle part of the West Bank with a total area of $855 \mathrm{~km}^{2}$ [6]. It occupies approximately $14.5 \%$ of the West Bank area. Currently only $4.35 \%$ of the District is inhabited by Palestinian built up area, while approximately $20.3 \%$ is occupied by either Israeli settlements, nature reserves or closed military areas [7].

The number of inhabitants in the District is about 284,960 , in 15 municipalities and 53 village councils, 2 project committees and 5 refuge camps [8]. In Ramallah district a landfill site was established in the late 1960s, with an original area of about $4500 \mathrm{~m}^{2}$. Although it was a random dumpsite, it was located far from urban areas. Burning the garbage was common so that the total accumulation of solid waste was limited. Since the early 1990s, however, the municipality stopped burning wastes as the built-up areas expanded toward the dumpsite and smoke and toxins spread over residential and industrial areas [9]. As a result of that many restrictions were imposed on the process of collecting solid waste to minimize the amount gathered. In addition to that the landfill site of al-Bireh (a twin city of Ramallah) was closed. This situation has resulted in the spread of garbage in the streets in addition to many randomly distributed dumpsites in residential areas, threatening the environmental health of the Palestinian population.

The problem became more complicated when the nearby town of Beituniya closed its landfill, as this site was also located within the populated area which became harmful for 


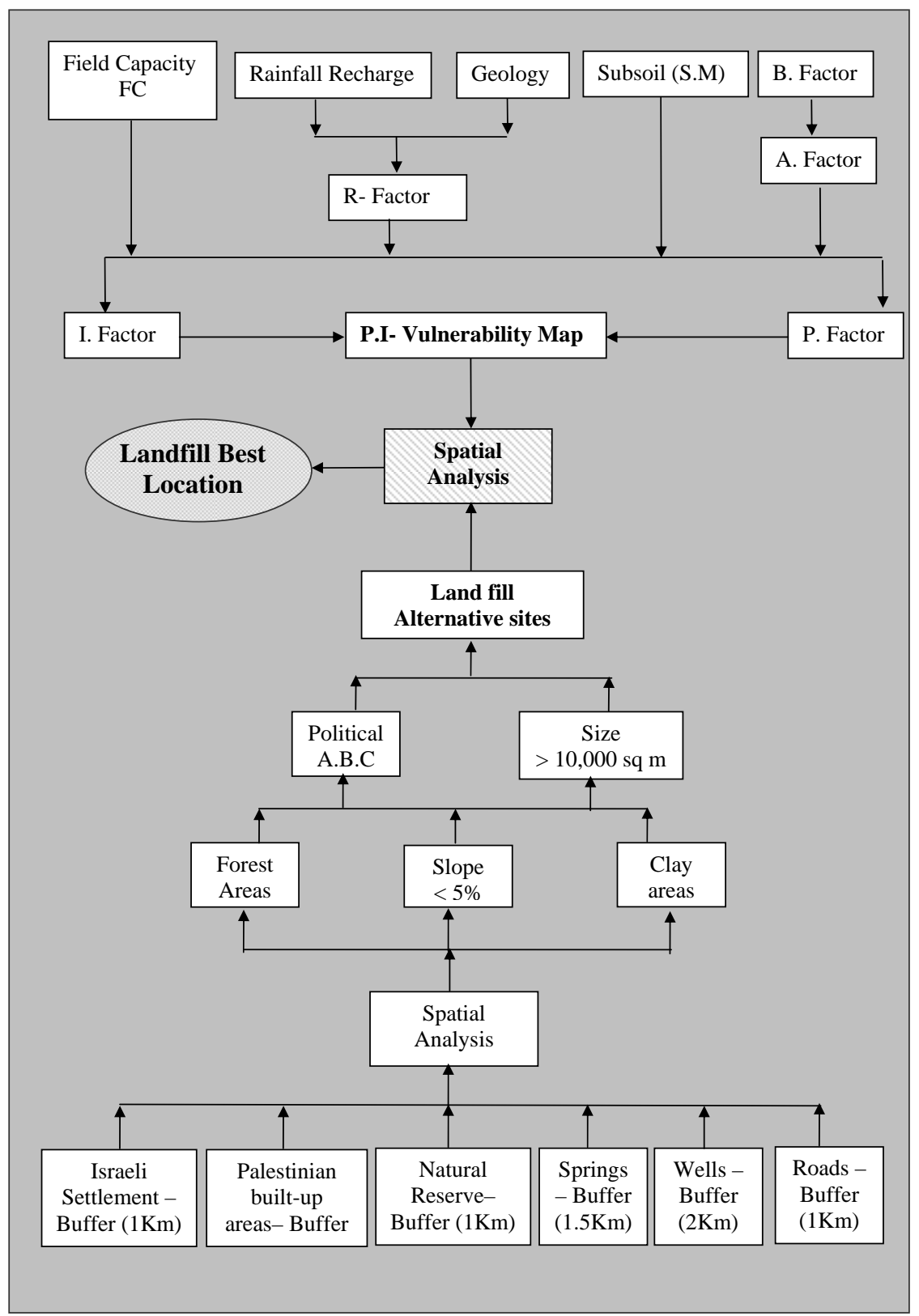

Fig. (1). Methodology (layers prepared).

public health, and began to use the Ramallah landfill in 1996 [9].

Al-Bireh city, adjacent to Ramallah city, had its own dumping site outside its boundaries since 1981. The landfill is considered to be in area $\mathrm{C}$ (controlled by the Israeli military) that closed the landfill after the Second Intifada in 2002. After closing both landfills in Ramallah and Albireh, more than 100,000 people became without any available proper landfill [10].

hrough the second Intifada (2000) the solid waste management in the West Bank became worse because solid waste can not be transported to reach dump sites outside municipal boundaries. As a result of that many vacant areas within city limits were used as dump sites without taking any measures into consideration [11]. Different types of solid waste are produced in Ramallah district like commercial, medical, agricultural, industrial, and domestic. The main one is the domestic solid waste; it forms more than $60 \%$ of the total solid waste while the other contributes with less than $40 \%$. The solid waste generation in Ramallah district is estimated by 480 ton per day [12]. This leads to the urgent need to search for a landfill site to serve the governorate and to be allocated according to scientific standards that meets sustainability.

\section{METHODOLOGY AND ANALYSIS}

In this paper, GIS plays a major role in determining the "best location" for a landfill site according to predefined criteria based on scientific standards and measurements. The 
aim is to avoid the need for impact mitigation and ongoing management by selecting a site where natural barriers protect environmental quality and where there will not be adverse impact on existing and future development [3].

To build a GIS model, the following layers were used (Fig. 1): Geological formation, rainfall, district boundary, built-up area, natural reserves, settlements, major roads, local roads, land use, springs, wells, ground water, Infiltration conditions (I)-map, and Protective cover (P)- map, soil type, and topography.

\subsection{Groundwater Vulnerability}

The origin-pathway-target model was adopted in order to come up with vulnerability map for the study area by PI Method. The PI Method is based on an origin-pathway-target model: The origin of the assumed hazard is the ground surface; the groundwater table in the uppermost aquifer is the target; the pathway includes the layers between the ground surface and the groundwater surface [13]. Thus, the PI method can be used for resource vulnerability mapping. However, if the resource vulnerability map is intersected with a map showing the flow route in the aquifer towards a spring or well, it can also be used for source vulnerability mapping.

$\boldsymbol{P}$ is divided into five classes. From $\mathrm{P}=1$ for a very low degree of protection to $\mathrm{P}=5$ for very thick and protective overlying layers. Where "I " describes the infiltration conditions, particularly the degree to which the protective cover is bypassed as a result of lateral surface and subsurface flow in the catchment's of swallow holes and sinking streams. The " $I$ " factor is 1.0 if the infiltration occurs diffusely, e.g. on a flat, highly permeable and free draining surface. In contrast, the protective cover is completely bypassed by a swallow hole, through which surface water may pass directly into the karst aquifer the "I" factor is 0.0 in such a case. The catchment's of a sinking stream is assigned a value between 0.0 and 1.0, depending on the proportion of lateral flow components. The I map shows the spatial distribution of the I factor.

The final protection factor $\Pi$ is the product of $\mathrm{P}$ and $\mathrm{I}$. It is subdivided into five classes. A protective factor of $\Pi \leq 1$ indicates a very low degree of protection and an extreme vulnerability to contamination; $\Pi=5$ indicates a high degree of protection and a very low vulnerability.
The vulnerability map is obtained by intersecting the $P$ map with the I map, where the P map shows the effectiveness of the productive cover as a function of the thickness and permeability of all the strata above the Groundwater surface, and the I map shows the degree to which the protective cover is bypassed.

\subsection{GIS Procedure for Landfill Site Allocation}

To get the proper site for landfill in Ramallah district from the base map, the following procedure was followed:

Step 1: Create vulnerability map:

$\boldsymbol{P T S}=[T+\{S M+\Sigma B M\} * R+A]$

Pts $=$ total protective function

$\mathrm{T}=$ Field Capacity for top soil

$\mathrm{S}=$ Grain size distribution for subsoil

$\mathrm{M}=$ Thickness of each stratum in

$\mathrm{B}=$ Bedrock

$\mathrm{R}=$ Recharge

$\mathrm{A}=$ Artesian pressure

And so the following maps were created

- Apply the above equation to create the Pts map

- Apply the relation between Pts and P to create P map

- Multiply P map with I map to create the vulnerability map.

Other needed layers:

1. Field capacity for top soil 2.Rainfall recharge for Ramallah district 3.R-factor for geological formations 4. Subsoil (S) thickness (M) values for subsoil 5.Bedrock for geological formation 6 . Sum of $\mathrm{B}^{*} \mathrm{M}$

\subsection{Artesian Pressure}

\section{Field Capacity Map}

Field Capacity (FC) is the ability of the top soil to store water, increasing field capacity means high capacity to store water. The table below (Table 1) shows field capacity for soils found in the Ramallah District based on type of soil and effective field capacity (e FC), then map that shows the different values of field capacity according to soil type was created.

Table 1. Field Capacity for Soil Found in the Ramallah District (HWE, 2007)

\begin{tabular}{|c|c|c|}
\hline Types of Soil & eFC (mm) Up to 1m Depth & Field Capacity (T) \\
\hline \hline Grumusols & 460 & 750 \\
\hline Terra Rossa, Brown Rendzinas \&Pale rendizinas & 446 & 750 \\
\hline Brown Rendzinas \&Pale rendizinas & 334 & 750 \\
\hline Brown Lithosols \&Loessial arid brown soils & $140-200$ & 250 \\
\hline Loessial serozems & $140-200$ & 250 \\
\hline Brown lithosols \&Loessial serozems & $90-140$ & 125 \\
\hline
\end{tabular}


Table 2. R-factor for Geological Formation in Ramallah District

\begin{tabular}{|c|c|c|}
\hline Formation & Recharge $[\mathrm{mm} / \mathbf{y}]$ & R-factor \\
\hline \hline Lower cenomainan & 7 & 1.75 \\
\hline Upper cenomainan & 226 & 1.25 \\
\hline Turonian & 105 & 1.5 \\
\hline Senonian & 7 & 1.75 \\
\hline Albian & 135 & 1.5 \\
\hline Quaternary & 11 & 1.75 \\
\hline Lower cretaceous & 11 & 1.75 \\
\hline Eocene & 180 & 1.5 \\
\hline
\end{tabular}

\section{Recharge Map}

Recharge is the amount of rainfall that percolates through the land surface to arrive at the water table. The values of recharge have been calculated based on the equations below [8]:

$$
\begin{array}{ll}
\mathrm{r}=0.6 *(\mathrm{P}-285) & \text { for } \mathrm{P}>700 \mathrm{~mm} \\
\mathrm{r}=0.46 *(\mathrm{P}-159) & \text { for } 700>\mathrm{P}>456 \mathrm{~mm} \\
\mathrm{r}=0.3 *(\mathrm{P}) & \text { for } 456 \mathrm{~mm}>\mathrm{P}
\end{array}
$$

Where $\mathrm{r}=$ Recharge from rainfall in $\mathrm{mm} /$ year.

$\mathrm{P}=$ Annual rainfall in $\mathrm{mm} /$ year. lows:

The Procedure to calculate Recharge-factor $(\mathrm{R})$ is as fol-

1- Integrate geology map with rainfall map for Ramallah District with its amount of rainfall (p), then the rainfall recharge (r) was calculated based on above equations (Table 2).

2- Determine the R-factor based on COST Action 620 method [14].

\section{Subsoil}

The subsoil is the soil layer that lies below the top soil, it consists of gravel, sand, silt, and clay. Grain size distribution can be used as a means to evaluate the protective function of the subsoil as shown in (Table $\mathbf{3}$ ).

\section{Lithology and Fracturing}

The lithology $(\mathrm{L})$ is the physical makeup, including the mineral composition, grain size, and grain packing, of the sediments or rocks that make up the geological system. While fracture $(\mathrm{F})$ is a natural phenomenon occurs in rocks and causes separation into pieces under the action of stress. However the bedrock (B) is the multiplication between two factors lithology and fracturing see Table (4).

The depth which the pollutants pass in order to reach groundwater is $\mathbf{M}$, and can be obtained from two maps (water level and topography map). Also it can be calculated from this equation:

$$
\mathbf{M}=\mathrm{E}-\mathrm{W}
$$

Where: $\mathrm{E}$ is the elevation for formation

$\mathrm{W}$ is the water table above see level.

Procedure followed to calculate BM factor:

- union between water table and topography maps.

- Calculating the depth $\mathrm{M}$ to groundwater level based on equation (2).

- Determining typical thickness $m$ for each geological formation due to their appearance to surface as shown in Table (5) by using stratigraphical section for the West Bank.

After determining $\mathrm{m}$, and $\mathrm{b}$ for each geologic formation, the following equation was applied to find the sum of bedrock multiplied by groundwater thickness.

$$
\Sigma \mathrm{BM}=\boldsymbol{\Sigma} \text { bimi }
$$

\begin{tabular}{|c|c|c|c|c|}
\hline Types of Soil & $\begin{array}{c}\text { Type of Subsoil "Grain Size } \\
\text { Distribution" }\end{array}$ & S (Value) & Thickness of Soil (M) & $\mathbf{S} * \mathbf{M}$ \\
\hline Grumusols & Clay & 500 & 1.0 & 500 \\
\hline Terra Rossa, Brown Rendzinas \&Pale rendizinas & Clayey loam & 400 & 0.5 & 200 \\
\hline Brown Rendzinas \&Pale rendizinas & Clay & 500 & 1.5 & 750 \\
\hline Brown Lithosols \&Loessial arid brown soils & Slitly clayey sand & 75 & 0.5 & 37.5 \\
\hline Loessial serozems & loamy & 400 & 1.5 & 600 \\
\hline Brown lithosols \&Loessial serozems & Sility clay & 320 & 1.0 & 320 \\
\hline
\end{tabular}

\section{Artesian Pressure}

The artesian pressure of the geologic formation depends on the type of aquifer for that formation, i.e. confined or unconfined. The confined aquifers occur where groundwater is confined under pressure greater than atmospheric by overly-

Table 3. SM Values for Subsoil (Palestinian Hydrology Group, 2007) 
Table 4. Lithology and Fracturing for Geological Formation (Water Authority, 2007)

\begin{tabular}{|c|c|c|c|c|}
\hline Formation & lithology & $\mathbf{L}$ & $\mathbf{F}$ & $\mathbf{B}=\mathbf{L}^{*} \mathbf{F}$ \\
\hline Quaternary & Nari (surface crust) and alluvium gravels and fan deposits & 5 & 4.0 & 20 \\
\hline Eocene & Reefal limestone & 5 & 0.5 & 1.5 \\
\hline Senonian & Marl, chalk, chert & 20 & 25.0 & 500 \\
\hline Upper cenomainan & Karstic Dolomite & 5 & 0.3 & 1.5 \\
\hline Upper cenomainan & Limestone and dolostone & 5 & 0.3 & 1.5 \\
\hline Albian & Reefal limestone & 5 & 0.3 & 1.5 \\
\hline
\end{tabular}

Table 5. Bedrock Values and Typical Thickness for Geological Formations

\begin{tabular}{|c|c|c|c|c|c|c|c|c|c|c|c|c|c|c|c|}
\hline F & $\mathrm{b} 1$ & $\mathrm{~b} 2$ & $\mathrm{~b} 3$ & $\mathrm{~b} 4$ & $\mathrm{~b} 5$ & $\mathrm{~b} 6$ & $\mathrm{~b} 7$ & $\mathrm{~b} 8$ & $\mathrm{~m} 1$ & $\mathrm{~m} 2$ & $\mathrm{~m} 3$ & $\mathrm{~m} 4$ & $\mathrm{~m} 5$ & $\mathrm{~m} 6$ & $\mathrm{~m} 7$ \\
\hline Q 1 & 20 & 1.5 & 500 & 1.5 & 1.5 & 100 & 20 & 1.5 & 155 & 380 & 278 & 115 & 330 & 330 & 497 \\
\hline E 2 & 20 & 1.5 & 500 & 1.5 & 1.5 & 100 & 20 & 1.5 & 0 & 380 & 278 & 115 & 330 & 330 & 497 \\
\hline S 3 & 20 & 1.5 & 500 & 1.5 & 1.5 & 100 & 20 & 1.5 & 0 & 0 & 278 & 115 & 330 & 330 & 497 \\
\hline T4 & 20 & 1.5 & 500 & 1.5 & 1.5 & 100 & 20 & 1.5 & 0 & 0 & 0 & 115 & 330 & 330 & 497 \\
\hline U.C 5 & 20 & 1.5 & 500 & 1.5 & 1.5 & 100 & 20 & 1.5 & 0 & 0 & 0 & 115 & 330 & 330 & 497 \\
\hline Y (e) 6 & 20 & 1.5 & 500 & 1.5 & 1.5 & 100 & 20 & 1.5 & 0 & 0 & 0 & 0 & 330 & 330 & 497 \\
\hline Y(w) 7 & 20 & 1.5 & 500 & 1.5 & 1.5 & 100 & 20 & 1.5 & 0 & 0 & 0 & 0 & 0 & 330 & 497 \\
\hline A 8 & 20 & 1.5 & 500 & 1.5 & 1.5 & 100 & 20 & 1.5 & 0 & 0 & 0 & 0 & 0 & 0 & 497 \\
\hline
\end{tabular}

Where:

b: bedrock. m: thickness for each formation. Q: Quaternary. E: Eocene. S: Senonian.

T: Turonian. U.C: Upper cenomainan. Y (e): yata lower cenomainan, east. Y (w): yata lower cenomainan,weat. A : Albian.

Table 6. Types of Formation in Ramallah District Based on Zwahlen (2004)

\begin{tabular}{|c|c|c|}
\hline Formation & Type & A-value \\
\hline \hline Lower cenomainan & Confined & 1500 \\
\hline Upper cenomainan & unconfined & 0 \\
\hline Turonian & unconfined & 0 \\
\hline Senonian & unconfined & 0 \\
\hline Albian & Confined & 1500 \\
\hline Quaternary & unconfined & 0 \\
\hline Lower cretaceous & Confined & 1500 \\
\hline Eocene & unconfined & 0 \\
\hline
\end{tabular}

ing relatively impermeable strata. While unconfined aquifer is one in which a water table varies in undulating form and in slope, depending on areas of recharge and discharge, pump age from wells and permeability as shown in Table (6).

\section{P-Map}

The total protective function (PTS) was calculated according to equation (1), then the p-factor was constructed according to cost action 620 method (Zwahlen, 2004) as follows: for PTS between (1000-10000) that means it has high protective cover and has $\mathrm{P}$-factor value 4 while the other classification was larger than (10000) which means that it has a very high protective cover and has $\mathrm{P}$-factor value 5 and when PTS has value less than 1000, it gives $\mathrm{P}$ a value of 3 (Fig. 2).

\section{I -map}

I factor express the degree to which protective cover is bypassed by lateral surface and subsurface flow the spatial distribution of I factor was shown on I map (Fig. 3) (PHG, 2006).

\section{Vulnerability Map}

Finally Vulnerability map was obtained by making a union between I map and P map which shows the intrinsic vulnerability and the natural protection of the upper aquifers. PI factors ranges between 0.0 (high Vulnerability) and 5.0 (low Vulnerability) as shown in (Fig. 4). 


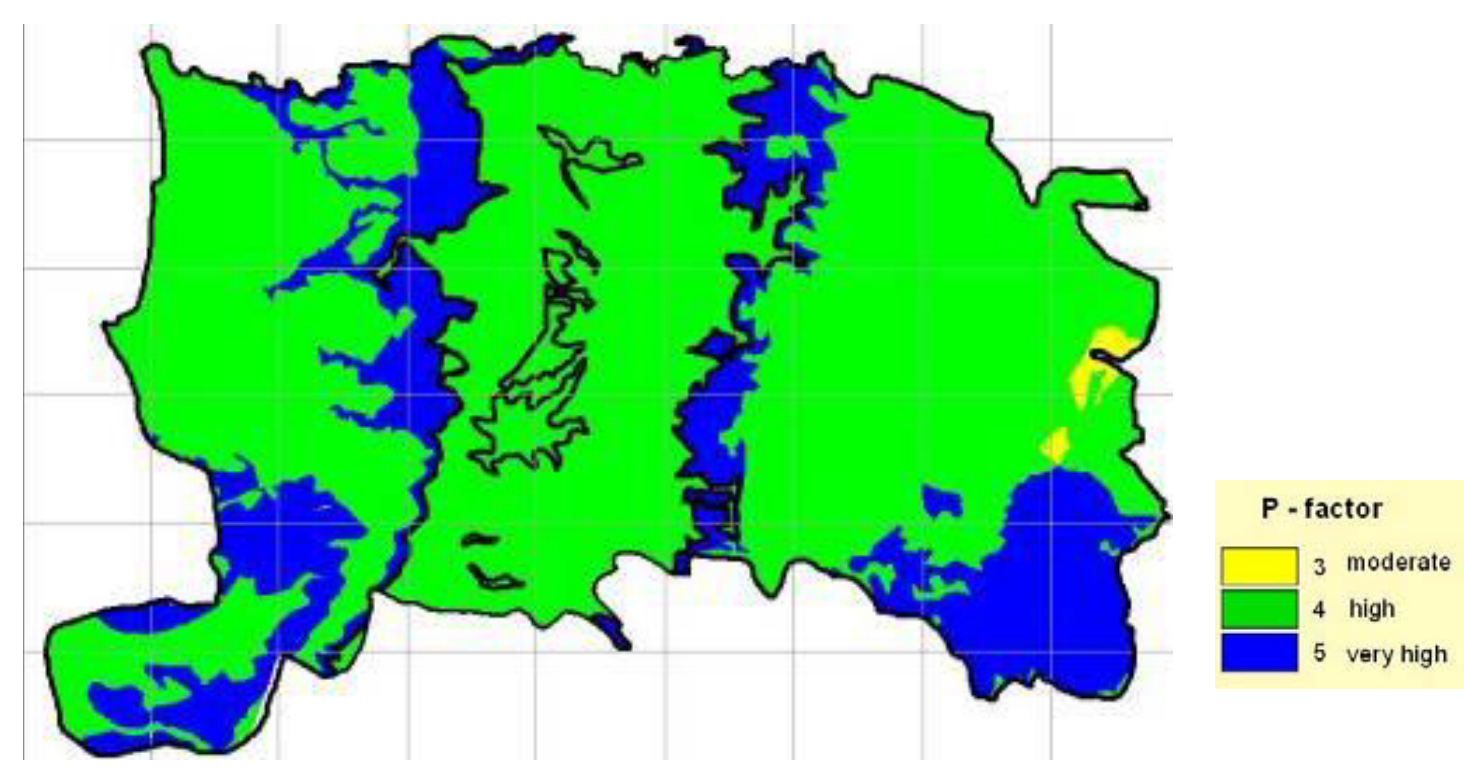

Fig. (2). Protective cover map (P map) [15].

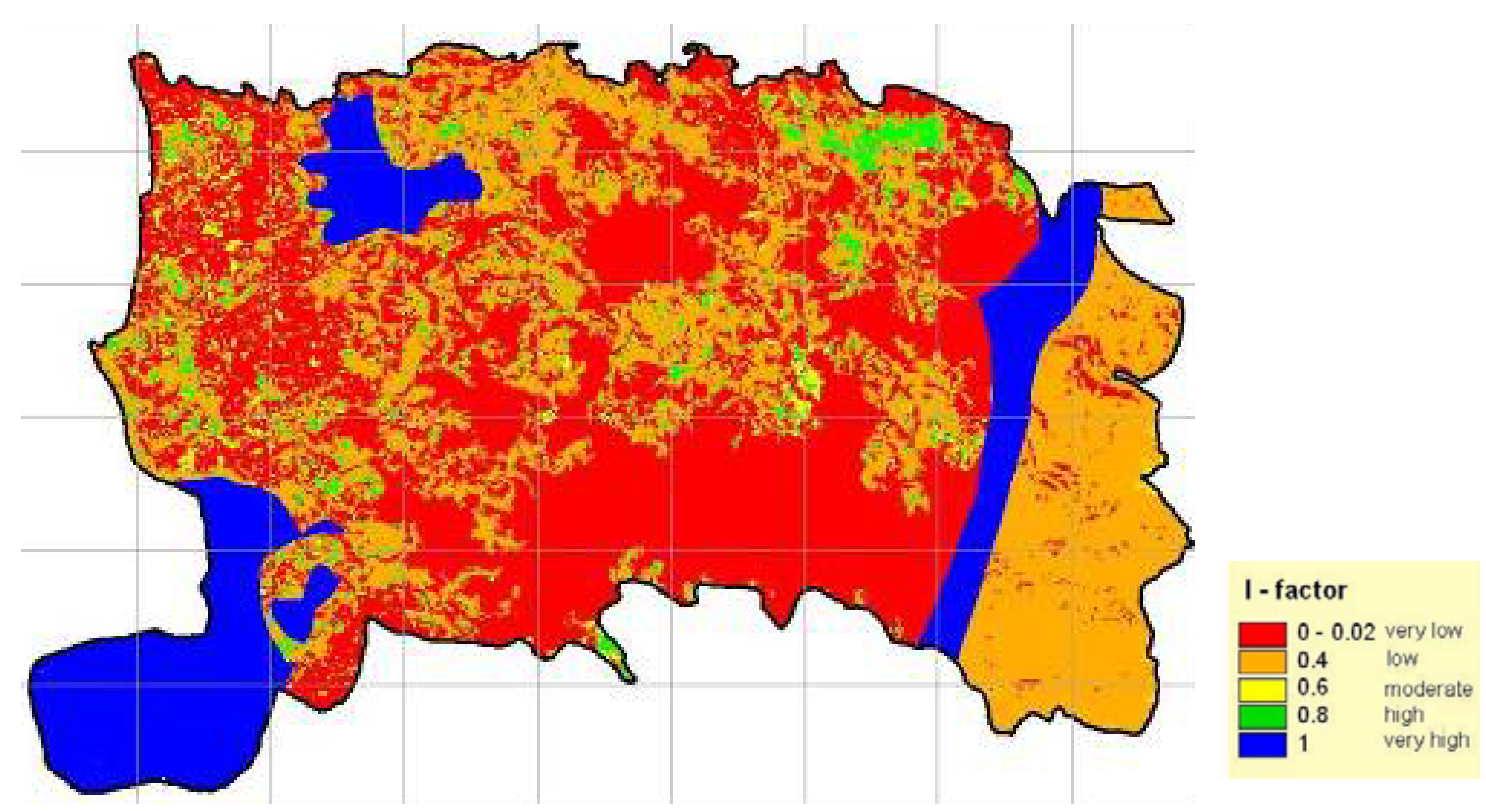

Fig. (3). I map for Ramallah district [15].

\subsection{Available Areas by Buffer Zones}

To find the excluded areas based on the criteria listed in (Fig. 1), the following buffer zones were created.

\section{Israeli Settlement}

The landfill site is prevented to be located within $1 \mathrm{~km}$ from the Israeli settlements; a $1 \mathrm{~km}$ buffer around the Israeli settlement was created. So the available area excluded buffer zone around Israeli settlements was calculated by subtracting it from the whole area of Ramallah district.

\section{Built Up Area}

The landfill site is prevented to be located within $1 \mathrm{~km}$ from the any built up areas, a $1 \mathrm{~km}$ buffer around the built up area was created. So the available area excluded buffer zone around Palestinian built up areas was calculated by subtracting it from the whole area of Ramallah district.

\section{Natural Reserves}

The landfill site is prevented to be located within $1 \mathrm{~km}$ from natural reserves; a $1 \mathrm{~km}$ buffer around natural reserves was created. So the available area excluded buffer zone 


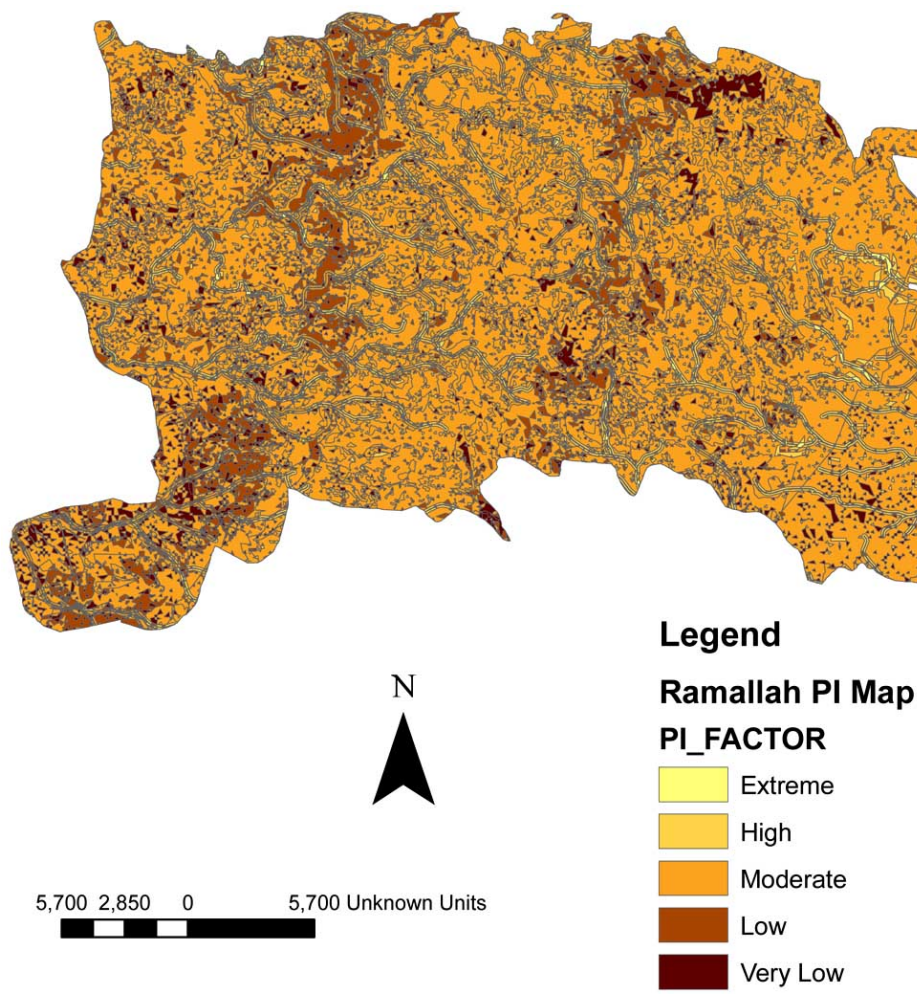

Fig. (4). Vulnerability map for Ramallah District [15].

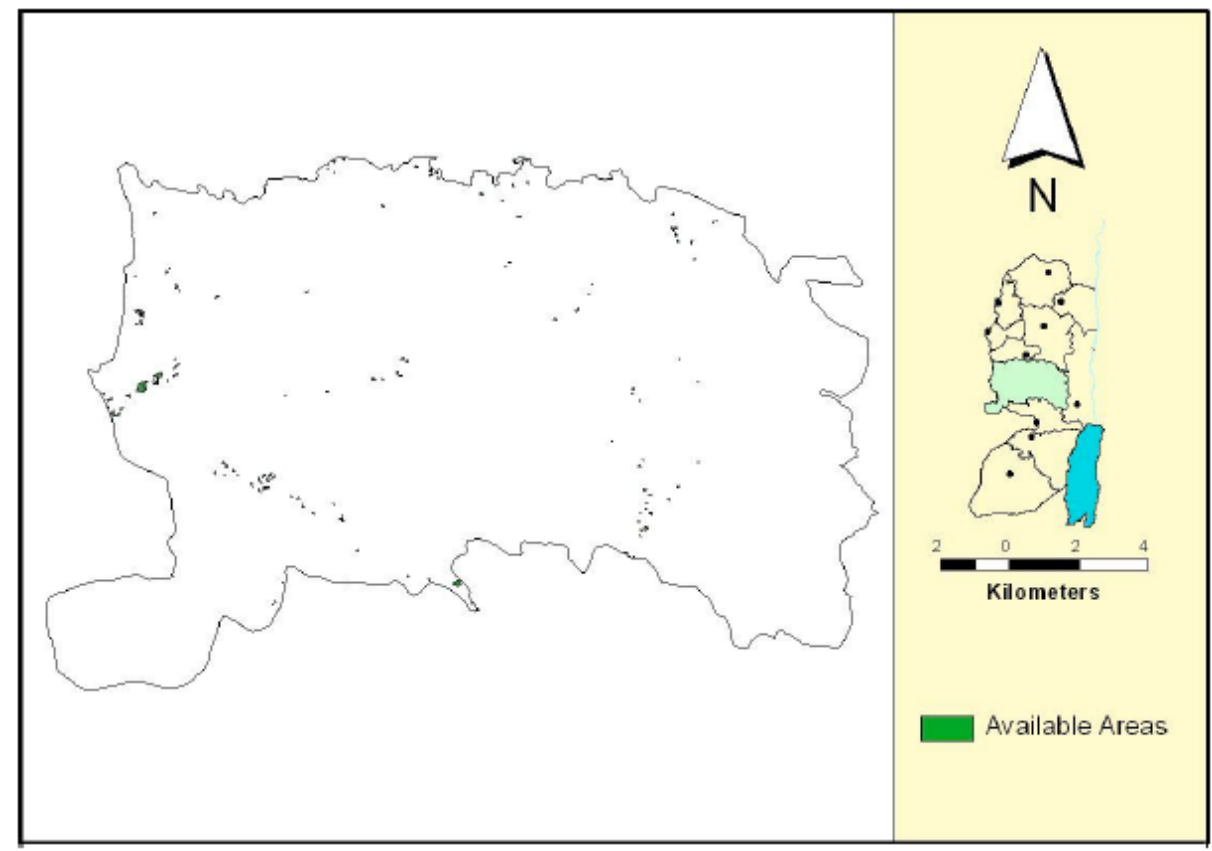

Fig. (5). Available areas for landfill site.

around natural reserves areas was calculated by subtracting it from the whole area of Ramallah district.

\section{Springs}

The landfill site is prevented to be located within $1.5 \mathrm{~km}$ from the springs; a $1.5 \mathrm{~km}$ buffer around springs was created. So the available area excluded buffer zone around springs was calculated by subtracting it from the whole area of Ramallah district.

\section{Wells}

The landfill site is prevented to be located within $2 \mathrm{~km}$ from the wells; a $2 \mathrm{~km}$ buffer around wells was created. So the available area excluded buffer zone around wells areas 
Table 7. Available Areas for Landfill Site with Area > 10 Donums

\begin{tabular}{|c|c|c|c|}
\hline 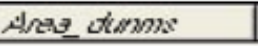 & Type & Type & Whese \\
\hline 17.71087371970 & Forest & Area C & WestBank \\
\hline 17.71087371970 & Forest & Area C & WestBank \\
\hline 10.22531045470 & Forest & Area B & WestBank \\
\hline 87.41459016010 & Forest & Area C & WestBank \\
\hline 64.86951388440 & Forest & Area C & WestBank \\
\hline 64.86951388440 & Forest & Area C & WestBank \\
\hline 12.04780989760 & Forest & Area C & WestBank \\
\hline 48.02683899690 & Forest & Area C & WestBank \\
\hline 92.44736385490 & Forest & Area C & WestBank \\
\hline 16.86554157230 & Forest & Area C & WestBank \\
\hline 11.13510197640 & Forest & Area C & WestBank \\
\hline
\end{tabular}

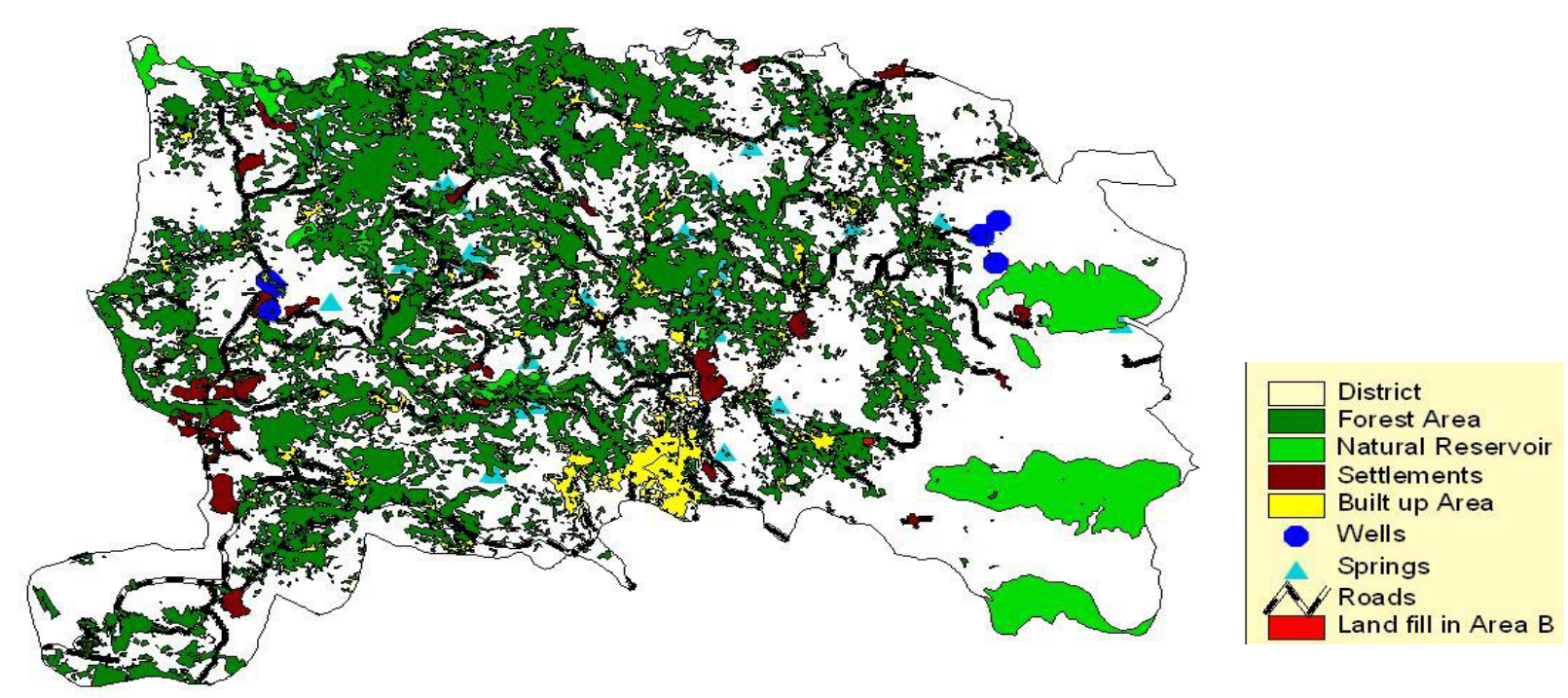

Fig. (6). Landfill location alternatives in Ramallah district.

was calculated by subtracting it from the whole area of Ramallah district

\section{AVAILABLE AREAS BY AREA CHARACTERISTICS}

In this step a query was done to find the areas that meet the following conditions based on criteria adopted by Palestinian Agency for Environmental Affairs (2006) for best location of landfill as shown in (Fig. 5):

Area should meet the following criteria:

- Land use $=$ forest

- Soil type = clay

- Slope $<5 \%$

\section{LANDFILL ALTERNATIVES}

To find the best location for a landfill site in Ramallah district, two criteria were formulated, the first is the area needed to construct a landfill site as estimated by Ramallah municipality, the needed area for landfill site should be at least 10 donums $\left(10,000 \mathrm{~m}^{2}\right)$, so a query was done to allocate the available area for landfill with an area of 10 donums or more (Table 7).
The second is the political aspects based on $(\mathrm{A}, \mathrm{B}$, and $\mathrm{C}$ regions);

According to Oslo agreement between Palestinian and Israelis, West Bank and Gaza were divided into three areas A, $\mathrm{B}$, and $\mathrm{C}$ areas. 'A' areas, controlled by the Palestinian Authority (PA), are mostly urbanized and not suitable for landfills. 'B' areas are administratively operated by the PA, but militarily controlled by the Israelis. ' $C$ ' areas are less urbanized, far from populated areas, and would be potentially adequate for constructing new landfill site but they are fully controlled by Israelis and so landfill construction in theses areas are restricted. So the landfill site should be placed in area "B".

The result was shown for the landfill alternatives (Fig. 6), a spatial analysis was conducted to delineate these alternative sites to the lands of low to very low vulnerability.

A query was done to find available landfill sites that are located in B areas. The result was a site with an area of 10.2 donums which is located near Dir-Dibwan village (Fig. 7) (30 km from Ramallah city). 


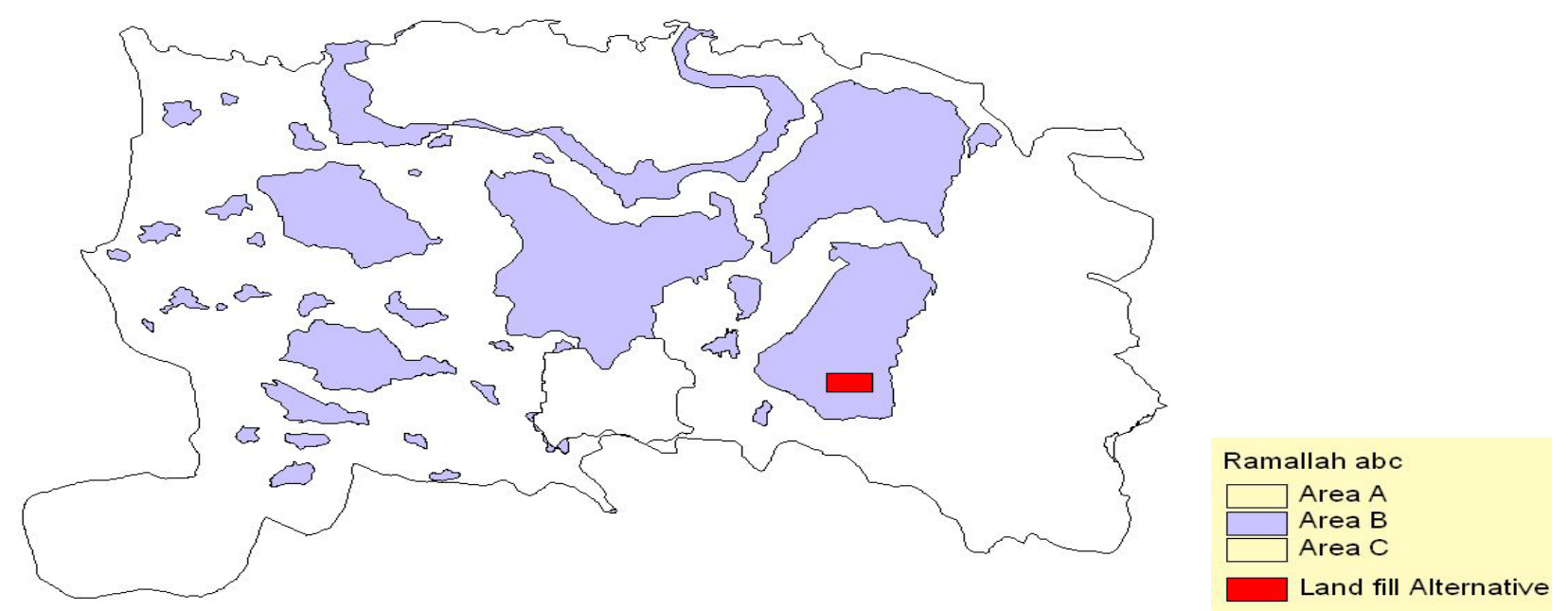

Fig. (7). Best location for a landfill in Ramallah district.

\section{CONCLUSION}

GIS could effectively be used as a management and an analysis tool that facilitates planning process. In this research, GIS software was used to locate the best landfill site for Ramallah district by creating maps according to scientific criteria and standards. Hence, it's worthy to recommend the application of this tool in different planning aspects and fields.

As discussed in the methodology flow charts and tables, more than thirty maps were created by using GIS analysis for Ramallah district. The research depended on two components: one is the vulnerability map which revealed the areas of less threat on nature.

The other is the buffer areas around sensitive spots and lines in order to find the best location for the landfill site taking wells, springs, natural reserves, springs, road network into consideration. Then by superimposing these two thematic maps the result was the best location for a landfill site taking all the mentioned criteria and standards into consideration.

The selected site located in areas with low to very low vulnerability which gives a high ability to prevent leachate comes from waste to reach ground water. Also the site is located in clayey area that has less permeability, with a slope less than $5 \%$ that will prevent any pollutant to be mixed with drainage water.

\section{REFERENCES}

[1] E., Mcfaden, Environmental hot spots report: identified and evaluated in Palestine, Italian Agency- Palestine. 2003.
[2] R. Friedman, Integrated Solid Waste Management. Mc Graw-Hill: University of California, 1998.

[3] (EPA) Environmental Protection Agency., Environmental Guidelines: Solid Waste Landfill, Environmental Protection Authority. 1996.

[4] Palestinian Agency for Environmental Affairs,. Ramallah, Solid waste standards report, 2006.

[5] R.A., de By. Principles of Geographic Information System, ITC, The Netherlands. 2004.

[6] M. Ezat, Ramallah and Al-Bireh the Twin Cities, Dar Al-Hekma, Beirut, 2000.

[7] (ARIJ) Applied Research Institute-Jerusalem., Environmental Profile for the West Bank, Jerusalem, 1998.

[8] (PCBS) Palestinian Central Bureau of Statistics, Population of Palestinian Communities, 1997-2010. Ramallah, Palestine, 1999.

[9] I. Al-khatib, R. Abu Safieh, Solid Waste Management in Emergency, Institute of Community and Public Health, Birzeit University. 2003.

[10] A. Shahi, and R. Najjar, "Solid Waste Management System and Landfill Design for Ramallah and Al-Bireh Governorate". Graduation Project, Birzeit University, Palestine, 2004.

[11] (PCBS) Palestinian Central Bureau of Statistics, Dumping Site Survey 2001. Ramallah, Palestine, 2001.

[12] Palestinian Ministry of Planning, Protection Plan for West Bank Governorate. Ramallah, Palestine, 1998.

[13] B. Adams, and S. Foster, Land-surface zoning for groundwater protection. Journal of Water Environment Management. Vol. 6, pp. 312-20, 1992.

[14] F. Zwahlen, Vulnerability and risk mapping for the protection of carbonate (karst) aquifers, EUR 20912. Brussels7 European Commission, Directorate-General XII Science, Research and Development, 2004.

[15] Z. Mimi and A. Assi, Intrinsic vulnerability, Hazard and Risk Mapping for Karst Aquifers: A case Study. Journal of Hydrology, Published by Elsevier, vol. 364(3-4): pp. 298-310, 2009.

(C) Mahamid and Thawaba; Licensee Bentham Open.

This is an open access article licensed under the terms of the Creative Commons Attribution Non-Commercial License (http://creativecommons.org/licenses/by-nc/3.0/g) which permits unrestricted, non-commercial use, distribution and reproduction in any medium, provided the work is properly cited. 